\title{
First Amendment Under Attack in Illinois Prisons: The Price of Dissent George Peter
}

xercising one's first amendment rights is analogous to breathing;
most of us only learn to appreciate it when our capacity to exercise it is impinged upon. However, there are certain events that heighten an individual's awareness of particular circumstances. For those of us incarcerated, we quickly discover how tenuous our ability to engage in first amendment activities are in a way that the average person takes for granted.

The magnificence of the Bill of Rights comes not from its uniqueness. Most of its principles are drawn from the "Liberties of Englishmen", won in the 17th century in Great Britain after a lengthy battle between parliament and the king. Rather, the Bill of Rights symbolizes the premise that the government exists for the benefit of the people and is based upon their consent. The first amendment reads:

Congress shall make no law respecting the establishment of religion, or prohibiting the free exercise thereof; or abridging the freedom of speech, or of the press, or of the right of the people peacefully to assemble, and to petition the government for a redress of grievances.

These are liberating words that afford every member in a collective body the opportunity to set forth their thoughts on whatever is important to them. Having been incarcerated since Lyndon B. Johnson was president, I have developed an insider's perspective of the Illinois prison system, an acute sense of the nuances and paradoxes of its operational procedures, and a discerning insight into the complex linkage between information and power.

When Illinois revised its Freedom of Information Act law in 2010, it afforded prisoners throughout the state the ability to gain an insight into how the Department of Corrections develops its rules and regulations, as well as how they are supposed to be implemented within the prison system. Armed with this knowledge, I began researching an issue that confronts nearly every American prisoner: substandard and inadequate food. It was my hope that my endeavours would garner the attention of officials who are in an oversight position within state government so that those individuals would take that responsibility and investigate the allegations I raised about mismanagement in the food system. While some of my points of contention were unique to the facility I was then confined in, the Hill Correctional 
Center, I believe that the investigative techniques I utilized are universal and can be applied to many problems we encounter.

On 16 April 2012, Hill instituted a "Brunch Program", which reduced the number of meals served daily from three to two with breakfast and lunch meals combined into one meal. In an April 2012 interview with the Lee Enterprise newspapers, the Corrections Director stated that the program would save the state $\$ 2.5$ million the following year (Belleville News Democrat, 2013, p. B5). To investigate further, I submitted a Freedom of Information Act (FOIA) request for a copy of the Master Menu to ascertain exactly what food items we should be receiving in order to meet nutritional standards. This document is prepared by the Department's Food Service Administrator and outlines the meals that are supposed to be served daily. It is prepared every fiscal year and operates on a rotating five-week schedule. I also sought any e-mails received by Hill concerning the implementation of the Brunch Program. Eventually, I received the requested documents.

I began charting every meal that was served over a one-month period and then compared it to how well it matched up with the Master Menu. Upon the completion of this analysis, it was apparent that there was a considerable disparity between what prisoners were supposed to be fed and what the Dietary Department was actually providing. I conducted a formal investigation into the reason why the meals we were being served were so dissimilar to those that were specified on the Master Menu. At that point in time, I did not know whether the facility was under funded or if the funding received was being misdirected for unauthorized purchases. My quest to unravel this mystery was a lengthy one.

After registering multiple complaints regarding the shortcomings of the meals with her office, the Food Service Administrator came to interview me in my residential unit during one of her regularly scheduled visits to Hill. She was accompanied by the Dietary Manager of the prison. Although I was able to secure some minor improvements in our diet, including the introduction of tuna and fresh apples, these changes fell far short of the Master Menu's requirements. It was "back to the drawing board" with my efforts.

My initial breakthrough came when I was able to secure a copy of the Food Service Operations Manual because it provided me with the blueprint of how the Dietary Department was supposed to function. I was now in possession of information regarding how the prison purchased its food, how substitutions could be made when the kitchen temporarily ran out of 
a particular food item and how the substitution was supposed to be of an equal nutritional value. Most importantly, I learned that the Institutional Directive G5.01.127 states the following: "Employees shall be served the same menu as provided to offenders".

For years, I have been stating that employees were fed a more nutritious diet than prisoners. When the John Howard Association (JHA) of Illinois investigated this issue, the Department replied that there was no rule or regulation mandating them to provide equal meals to employees and prisoners. Clearly, the Department either willingly misinformed the JHA or were ignorant of the requirement; where the truth lies in this matter, I have yet to discover. To bolster the presentation I was assembling, I compiled a list of all the food items made available to employees, but not to prisoners. The following is a compilation of the extra food they receive in addition to the regularly-scheduled meal: sliced cheese, tuna salad, cookies, dry cereal, apples, celery, carrots, tomatoes, bell peppers, shredded cheese, potato chips and popcorn, crackers, raw eggs (for boiled eggs or potato salad), radishes and cucumbers.

Once I obtained this list, my next objective was to learn the approximate cost of the items. I submitted a FOIA request for the monthly purchase orders and invoices for each item. This gave me a rough estimate of how much money was being spent on food that never reached a prisoner's plate. Two items in particular stood out: Hill spent up to $\$ 1,318.00$ per month for potato chips and popcorn, along with some $\$ 1,425.00$ for tuna. However, when I first arrived at Hill in 2010, tuna was not served to prisoners. It was only after my interview with the Food Service Administrator that the Dietary Manager occasionally served tuna under her directive. However, I was not able to secure the issuance of popcorn or potato chips on a more frequent basis.

At about the same time that I was gathering this information, an article was published in a local newspaper which outlined a supplemental appropriations request from the Department seeking an additional $\$ 40.5$ million from the Illinois House Public Safety Appropriations Committee (Belleville News Democrat, 2013, p. B5). One of the stated reasons for the need of the supplemental funding was because it had cost the Department some $\$ 200,000$ per facility to implement the Brunch Program. Due to my first-hand experience of the program and the information I had uncovered during my investigation, I found this assertion perfidious. 
Lacking any formal training as a forensic accountant, I did not know how to differentiate the cost ratio to be assigned to a food item (such as cheese) served to both prisoners and employees. However, I surmised that when one group can consume an item at will and the other only when it is listed on the Master Menu for a specific meal, an objective person would likely assess the majority of that item's expense to those individuals who have the most access to it. If my analysis is anywhere close to accurate, the amount of money being expended on food that employees should not have access to is well over $\$ 100,000$ at Hill alone. This raises serious questions about management of the food system and management of those funds.

I submitted all the information and supportive documentation I had gathered to each member of the House Public Safety Appropriations Committee, along with a detailed explanation. It was my hope that the Committee would not only look into the alleged cost of the Brunch Program, but also the disparity between the food served to prisoners and employees, which was in violation of the Department's own rules. As Illinois is all but bankrupt, I was hopeful that the elected officials of the state would be interested in eliminating waste, fraud and abuse. I was incorrect in this assumption.

The last three months of 2014 saw a marked increase in prisoner dissatisfaction throughout the state concerning the quality and quantity of food being provided. This resulted in a series of food strikes during which prisoners entered the dining room and refused to accept the preferred tray. When this occurred at Hill in early November, the facility was placed on lockdown while the administration attempted to identify those individuals who coordinated the strike. While I understood the frustration that led to the prisoners protesting the substandard food, described by the prison guards' union as "barely edible", I am not a proponent of open confrontation with the system and choose to rely upon my intellect to impact change from within.

As a vocal critic of the prison system's failure to abide by its own rules and regulations, I recognized the possibility that my endeavours to secure an improvement in the quality and quantity of the food served at Hill might expose me to additional scrutiny. I made this determination because I had observed what the Department of Corrections' officials were willing to resort to in order to preserve unwarranted privileges, including restricting access to information that might be used to curtail those privileges. To date, the Department has refused to release the initial evaluation of the Brunch 
Program although State law indicates that it is subject to release. 5 ILCS 140/ 2.5 reads as follows: "All records relating to the obligation, receipt, and use of public funds of the State, units of local government, and school districts are public records subject to inspection and copying by the public".

My appeal to Illinois' Public Access Counselor seeking the release of this document has been pending for nearly two years. Due to the Department's unwillingness to release the evaluation, one can only imagine the embarrassing information it contains. I was disillusioned by the tepid response I received from the House Public Safety Appropriations Committee. The prison system was recalcitrant in its refusal to comply with existing rules and regulations, while the legislative body charged with supervising the expenditure of state monies refused to investigate my allegations of impropriety within the Hill Correctional Center. I decided to try a different approach and chose to share my concerns with the public, believing that the best solution for corruption was "the light of day". Recalling the adage "a picture is worth a thousand words", I composed a cartoon (see Figure 1) that encapsulated the issue I sought to publicize. Although it was an acidic criticism of the prison system, it was factually accurate.

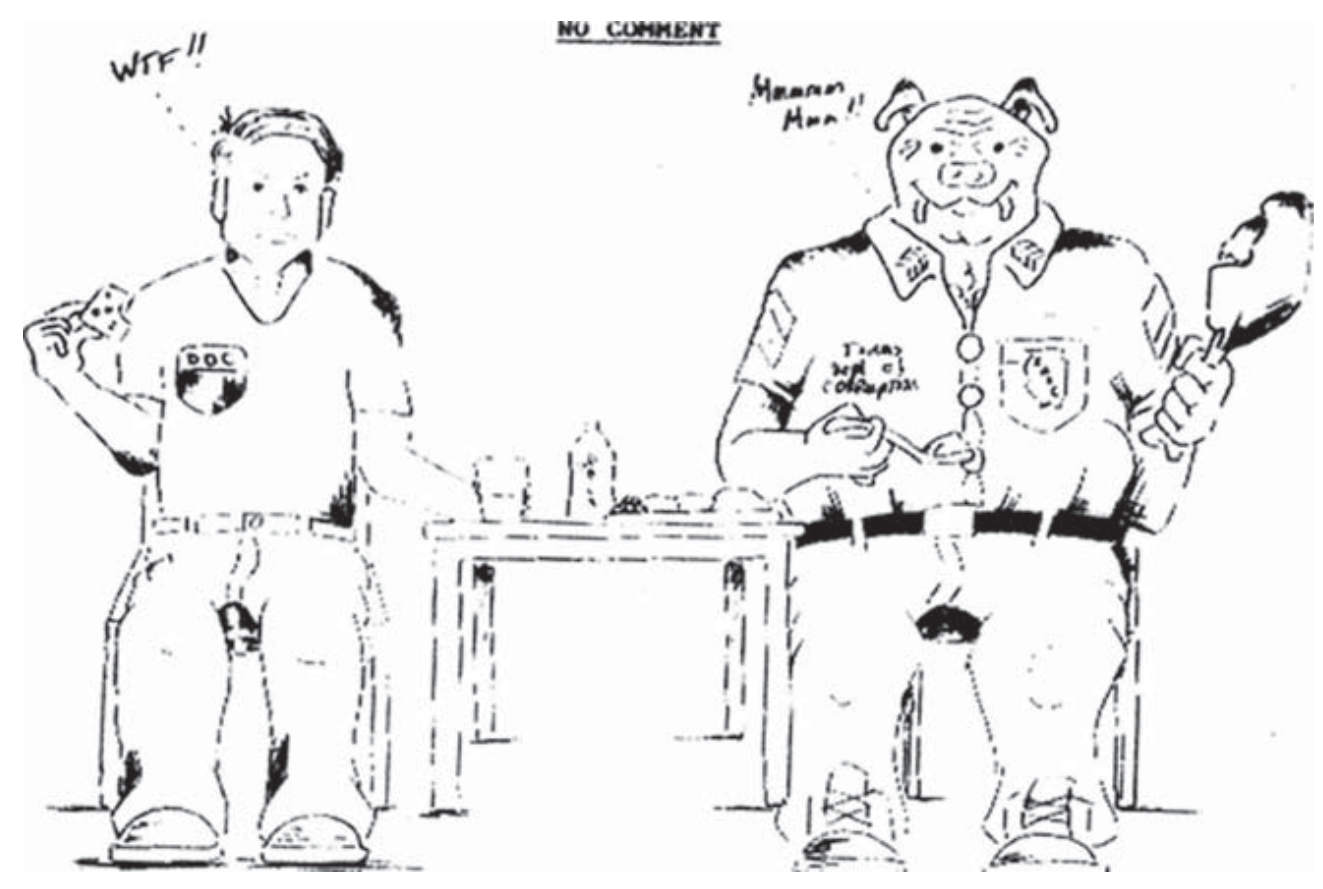

Figure 1: "No Comment" by George Peter 
On December $10^{\text {th }}$, I was summoned to the Internal Affairs Office and advised that my cartoon had come to the attention of the Director who was extremely displeased with it. In turn, I informed the hearing investigator that I was disappointed that the prison continued to refuse to comply with its own rules and regulations, even when presented with direct evidence of Hill's noncompliance with them. The first amendment clearly allows all citizens the right of free speech and to seek redress for our grievances (Hill, 2015), thus I intended to avail myself to whatever relief I may secure through the application of those rights. Although I had violated no rule of the Department, I had embarrassed its highest ranking official with my cartoon. In response, Internal Affairs placed me in segregation while they "investigated" me. Thirty days later, I was released without any disciplinary charge being written against me.

Shortly after my release back into the general population, several employees warned me that the administration was disappointed that the Director's Office had not authorized my transfer and that I should "watch my back". While I appreciated their concern, I recognized the fact that if the administration was determined to transfer me, they would eventually find a reason to do so. That reason would arise the following month.

On the day I was released from segregation, two employees from the Internal Affairs Office let me know that I would no longer be allowed to share a room with my best friend and confidant. Since I had done nothing to warrant being placed in segregation in the first place, I contacted the individual who assigned my friend to my room several years earlier and explained the situation to him. A query was then made on my behalf, but instead of acquiescing to that person's request I found myself being interrogated by an investigator from the Internal Affairs Office in Springfield concerning my relationship with employees, both within the Hill Correctional Center and throughout the state. Upon the completion of that roughly one-hour interview, Hill's administration once again placed me in segregation. The following day, I was issued a Disciplinary Report alleging that I possessed another prisoner's legal papers. When I appeared before the Adjustment Committee, I showed them a copy of Departmental Rule 430.30 which states: "Committed persons may assist one another in the preparation of legal documents to the extent consistent with institutional security".

The Committee ignored this Rule, found me guilty of the rule infraction and, shortly thereafter, I was transferred to the Western Illinois Correctional 
Center. While the story I have just shared may seem to have little importance, it demonstrates that the principle of free speech is under attack in American prisons and society more generally. Free speech is worth defending and incarcerated citizens should have the same civil rights as non-incarcerated citizens do in the USA.

When one raises the topic of free speech limitations, the mind summons to the forefront authoritarian countries, yet I am concerned with the gradual diminution of our free speech rights within my homeland and that the American beacon of democracy is slowly losing its potency in the eyes of the rest of the world. Whether you support the basic premise of this paper (i.e. the prison system should be held accountable when it refuses to comply with its own rules or regulations) or vehemently disagree with me, I support your right to have your voice heard. Our freedom of speech is a non-negotiable right.

\section{REFERENCES}

Belleville News Democrat (2013) “Two meals a day in state's prisons more expensive than expected" - October 26.

Hill, Tasha A. (2015) 'Inmates' Need for Federally Funded Lawyers: How the Prison Litigation Reform Act, Casey, and Iqbal Combine with Implicit Bias to Eviscerate Inmate Civil Rights", UCLA Law Review, 62: 179-235.

Kentridge, Sydney (1996) "Freedom of Speech: Is It the Primary Right?", The International and Comparative Law Quarterly, 45(2): 253-270.

\section{ABOUT THE AUTHOR}

George Peter, Jr. can be reached at the following address:

George Peter, Jr.

Reg. No. C-1434

Western Illinois Correctional Center

2500 Rt. 99 South

Mt. Sterling, Illinois 62353

USA 